\title{
Farm to abattoir conditions, animal factors and their subsequent effects on cattle behavioural responses and beef quality - A review
}

\author{
Yonela Zifikile Njisane ${ }^{1}$ and Voster Muchenje ${ }^{1, *}$
}

* Corresponding Author: Voster Muchenje Tel: +27-40-602-2059, Fax: +27-86-628-2967,

E-mail: vmuchenje@ufh.ac.za

${ }^{1}$ Department of Livestock and Pasture Science, University of Fort Hare, P. Bag X1314, Alice 5700, South Africa

Submitted Jan 14, 2016; Revised Feb 12, 2016; Accepted Sept 5, 2016

\begin{abstract}
The current review seeks to highlight the concerns that have been raised on preslaughter stress, contributing factors and its consequent effects on cattle behavioural responses and the quality of beef; inter-linking the activities involved from birth to slaughter. Such information is crucial in light of the consumer concerns on overall animal welfare, quality of meat and food security. Slaughter animals are exposed to different conditions during production and transportation to abattoirs on a daily basis. However; the majority of studies that have been done previously singled out different environments in the meat production chain, while conclusions have been made that the welfare of slaughter animals and the quality of meat harvested from them is dependent on the whole chain. Behaviour is a critical component used to evaluate the animals' wellbeing and it has been reported to have an effect on product quality. Apart from the influence of on-farm, transportation and abattoir conditions, the genetic background of the animal also affects how it perceives and responds to certain encounters. Stress activates the animals' hypothalamic-pituitary-adrenal activity, triggering release of various stress hormones such as catecholamines and cortisol, thus glycogen depletion prior slaughter, elevated ultimate $\mathrm{pH}$ and poor muscle-meat conversion. Pre-slaughter stress sometimes results to cattle attaining bruises, resulting to the affected parts of the carcass being trimmed and condemned for human consumption, downgrading of the carcass and thus profit losses.
\end{abstract}

Keywords: Slaughter-house; Transportation; Animal Welfare; Beef Farming; Biochemical and Behavioural Stress-indicators; Meat Quality

\section{INTRODUCTION}

According to Boissy and Erhard [1], animal welfare is a result of how animals identify with their surroundings and previous experiences. Different environments in the meat production chain, the factors around them and their effects on animal welfare and beef production have been reported in recent research outputs and reviews. Specifically, Waiblinger et al [2] looked at the interaction between humans and animals at the farm, concluding that it is a significant factor to consider in improving the welfare of farmed animals and the stockpersons. Good stockmanship has been reported to improve productivity [3], and this kind of treatment should begin at early stages of life $[4,5]$.

However, Ndou et al [6] highlighted that animal welfare and its further effects on product quality are highly considered in developed countries than the developing ones. They further hinted on the on-farm multipurpose cattle production systems and their consequences on beef quality. Work has been done on animal transportation conditions and their effects on animal welfare and meat quality [7,8], while Grandin [9] covered different livestock welfare issues at the farm and abattoirs, further relating them to consumer concerns. Moreover, Vimiso et 
al [10] reported that the African perspective on meat production and quality, particularly of the rural consumers have received little attention from the research areas.

All these issues in the meat production system have been separately covered without encompassing the whole production chain. However, the series of processes involved in meat production begins at the farm where animals are born, reared, fattened, transported to the slaughter-house, slaughtered and then converted to meat to be distributed to consumers through retailers. Miranda-de la Lama et al [8] described this phenomenon as the meat supply chain. Some studies that have been independently conducted on each of these events; predominantly the pre-slaughter occasions and they proved to induce stress to slaughter animals [11-17].

Some parts of the developed world have done a lot to develop measures to improve the animals' livelihood, together with ensuring good quality animal products for the consumers. However, some parts of the developing world such as Africa have been dragging behind due to several factors such as traditional customs and beliefs practised by different ethnic groups [6]. To ensure maximum product quality, this knowledge should be of importance to everyone in the production chain; from the stockman, farmer, transporter, abattoir worker, and the designers of animal facilities [18]. Therefore; knowledge of animal stress inducers, animal response-behaviour and its subsequent effects on meat product quality is of importance to ensure an efficient and economic enterprise.

\section{What happens when an animal is exposed to change?}

In trying to cope with a given situation, animals exhibit behavioural changes (Table 1), which can either be "positive" or "negative" and can be used as apparent animal welfare indicators $[18,19]$. The positive reflect normal and desirable behaviour; while the negative is a diversion from the normal. These behavioural changes can also be reflected through biochemical changes in the animal (Figure 1). Environmental unsettle activates the animals' hypothalamic-pituitary-adrenal activity due to fear [7], thus leading to some biochemical changes [20]. Various stressors result to release of stress hormones such as catecholamines and

Table 1. Some qualitative and quantitative descriptors to consider in examining animal response behaviour

\begin{tabular}{|c|c|c|}
\hline \multicolumn{2}{|c|}{ Qualitative behaviour } & \multirow{2}{*}{ Quantitative behaviour } \\
\hline Positive & Negative & \\
\hline Active, & Fearful & \multirow{7}{*}{$\begin{array}{l}\text { Standing immobile, approaching person } \\
\text { in contact with person, sniffing person, } \\
\text { vocalising, sniffing the environment and } \\
\text { moving away from person; flight zone, } \\
\text { exit speed, stepping and/or kicking }\end{array}$} \\
\hline Relaxed & Agitated & \\
\hline Calm & Irritable & \\
\hline Playful & Uneasy & \\
\hline Lively & Avoidance & \\
\hline Inquisitive & Restless & \\
\hline Un-phased & Vocalization & \\
\hline
\end{tabular}

Modified from: Bourguet et al [22], Dodzi and Muchenje [42], Mounier [56], Wemelsfelder et al [108], Waiblinger et al [109], Minero et al [110], Stockman et al [111]. cortisol, resulting to glycogen depletion prior slaughter, elevated ultimate $\mathrm{pH}$ and unacceptable conversion from muscle to meat $[16,21]$. Furthermore, Bourguet et al [22] observed that exercise and psychological stress just before slaughter increases muscle metabolic activity, which may continue after death, resulting in faster post-mortem $\mathrm{pH}$ decline and thus decreased meat quality [11].

Moreover, previous animal-human interaction relationships have been reported to be an influential factor and a determinant of how animals will perceive pre-slaughter exposure at a later stage. Boissy [23] reported that animals often perceive contact with a human being as a predatory encounter, to such an extent that they would panic and try to avoid human beings out of fear. Fear of humans by cattle can thus compromise animal welfare prior to slaughter, resulting in reduced productivity of quality meat [24]. However, good stockmanship at the farm is said to improve this problem such that animals are familiar with handling even prior to slaughter. In contrast, removal of animals from one environment to another for the purpose of slaughter has a potential to alter this perception.

Miranda-de la Lama et al [8] singled out transportation to be the link between all the activities that take place before slaughter. It has been found to greatly contribute to pre-slaughter stress [8,14,25-27]. Additionally, the effects of speed at which the transportation vehicle travels, the design of the vehicle (size, space, surface) and the stocking density during transportation were observed to contribute greatly to pre-slaughter stress [26]. Broom and Fraser [18] reported that lack of control in the animals' environment may result in strange behaviours in trying to adjust to physiological changes.

In addition, the abattoir environment offers the animals a new and different experience to that of the farm, with more confined structures and interactions thus behavioural and physiological adjustments required to get comfortable. Researchers have evaluated lairage conditions, slaughter processes-with or without stunning, bleed-out times and positions, duration between stunning and exsanguination together with their effects on animal welfare and meat quality [6,28-39]. Nevertheless, animal age, gender, breed, and species also play a role in the way animals individually respond to stress thus production $[15,24,40-42]$.

\section{The impact of the animals' background and characteristics on welfare thus production} Across species, the main contributing factor in selecting meat producing animals has always been the ability of the animal to produce a profitable quantity of quality meat in a given time. However, continuous research has shown significant links between the animals' response (behavioural and physiological) towards specific conditions and stimuli during the production cycle and thus the quality of meat that the animal produces. Specifically, temperamental cattle have been reported to be difficult to handle and are thus susceptible to handling stress, 


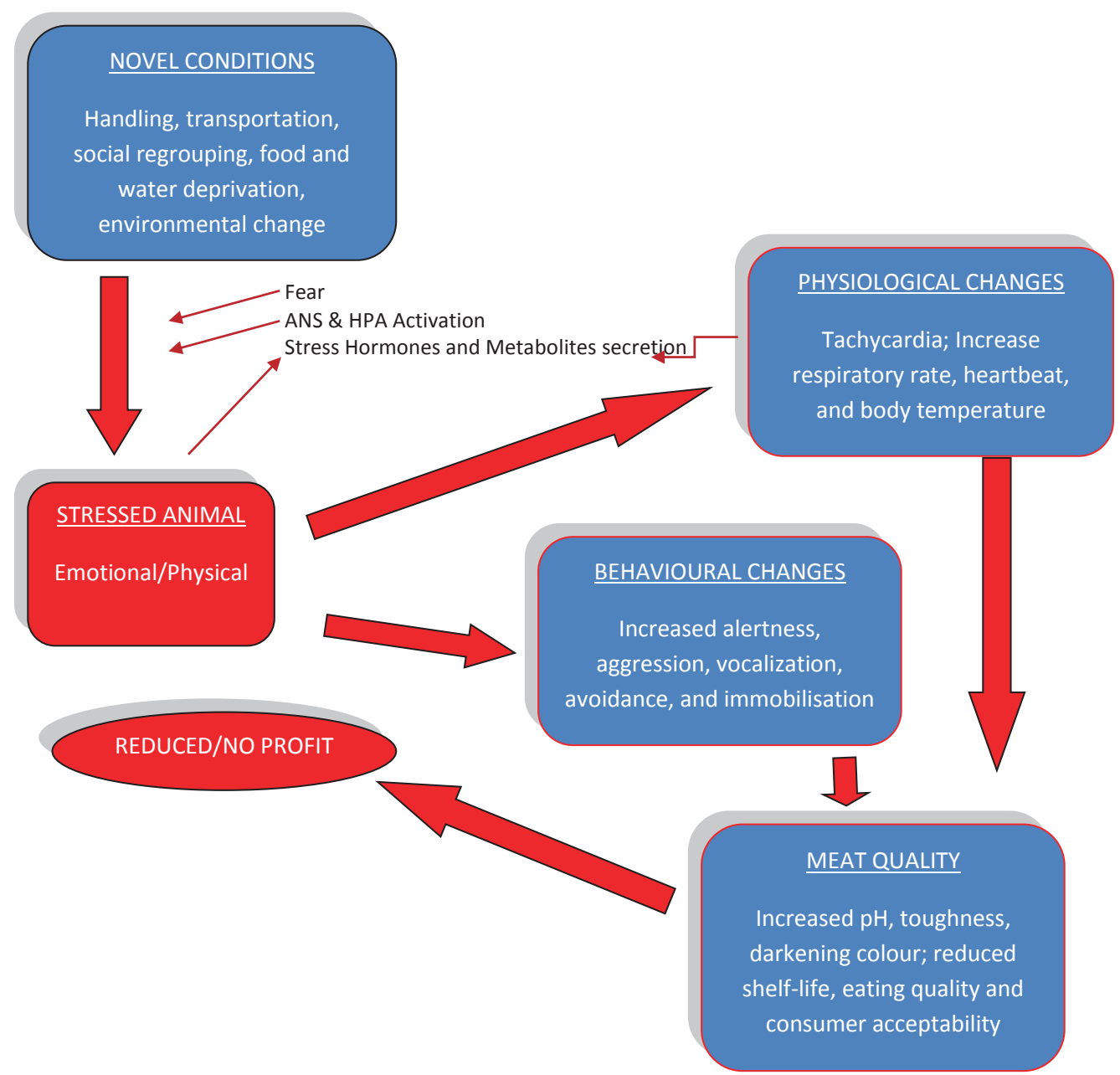

Figure 1. Diagram showing a detailed summary of the effects of the pre and slaughter process on the animals and the quality of meat, as described in literature. ANS, autonomic nervous system; HPA, hypothalamic pituitary adrenal.

resulting in poor meat quality $[43,44]$. An in-depth understanding reveals that the animals' intrinsic factors such as type of species, breed/genotype, age and gender contribute greatly to this perception and response $[35,36,42,45]$ thus meat quality $[15,24,40,41]$.

Furthermore, older animals have been reported to respond better (calm) than younger ones [35,36,46-48]. This may be due to their elongated exposure and experience, later developing some sense of tolerance. Studies on sheep reported that castrates were more relaxed and less fearful compared to ewes [35,36, $48,49]$ and this may be related to the differences in hormonal activities operating in the two genders. However, Dweyer [50] reported that male animals show more aggression, while the female species only engage in combative behaviour when competing for limited resources. Additionally, Njisane [51] reported that cross-bred cattle can be more temperamental compared to pure-bred cattle due to a mixture of different gene sequences, mainly aimed to producing quality meat product while the behavioural impacts may not be known. Grandin [43] also reported that animals that went through market-handling settle better in stressful environments like the abattoir due to similar previous experiences, compared to those sourced directly from the farm. However, it was also reported that cattle that have been markethandled through auctions tend to have more bruises than those sourced directly from farms [52].

\section{On-farm exposure conditions and activities}

Cattle farming has greatly contributed towards the success of the meat industry. Beef producing cattle are normally reared extensively during their early stages of life and then sometimes transferred to intensive systems during the fattening and finishing stages [4]. This system is believed to offer good animal welfare [53] and is characterised by free ranging and uninterrupted time budgeting, which can be classified as "normal behaviour" of cattle. Time-budgeting is an act of performing various activities like satiating hunger or thirst [54] animal-animal interactions for survival and pleasure purposes. The on-farm concept has been mostly established in the dairy production system, relating it to milk production $[42,55,56]$. However, the meat producing 
sector has given it very little attention even though it has a potential to determine and produce solutions to some of the challenges experienced, like in the dairy.

On-farm human-animal interactions, including time to time managerial activities and/or routines have, however, been ventured. Good stockmanship has been reported to improve productivity through reduction of fear and promotion of easy handling $[3,20]$. In addition, it has been recommended that farm animals be subjected to human contact from an early age in order to accustom them to human company for better handling at a later stage $[4,57,58]$. However, this may be a challenge to achieve in some countries that are still using the extensive production system to produce large herds of beef cattle to supply the meat industry with enough quantities to meet consumer demands and generate profit. This concept mostly accommodates dairy farmers whose production is already day to day, the stall farming systems and small units for research purposes.

However, higher cortisol levels during restraint are likely to be found in the extensively raised and less accustomed to handling beef cattle compared to dairy cows [59]. General human-animal interactions seen in beef farming include occasional managerial routines such as weighing, castration, dipping, branding, and vaccination, among others. Raussi [24] and Probst et al [4] reported these events to be unpleasant for animals, such that fear towards humans may be developed. Animals often recognise contact with human beings as destructive [23]. In order to deal with situations, animals may respond and even develop certain behaviours or strategies such as avoidance or clustering in trying to cope [60]. Furthermore, cattle and sheep can remember an aversive experience for many months after it occurs [61,62]. Therefore, the "pre-slaughter" preparation of cattle then remains an un-resolved problem.

\section{Pre-slaughter events and their impact on animal welfare} and productivity

Pre-slaughter events begin the moment animals are led and loaded on a truck/vehicle at the farm to be sent for slaughter. Ferguson and Warner [7] described pre-slaughter as the conditions and practices during which animals are moved at the farm through to the knocking box at the abattoir. At this stage animals are exposed to extra physical activity, way more than normal animal-human interaction and multiple unfamiliar persons. Grandin [11] reported that situations unfamiliar to the animals such as transport, pre-slaughter treatment and handling at the abattoir, can be extremely stressful to beef cattle. In addition, the abrupt change in their social or physical settings exacerbates trauma $[7,13,63]$.

\section{Transportation}

Miranda-de la Lama et al [8] described transportation as the key component joining the events involved in the pre-slaughter logistics chain. This process is largely an exceptionally stressful event in the animals' life [7,64]. It often involves novel and tense exposures such as crowding, noisy vehicles without access to food and water or space to rest, pre-transport management, vibrations, social regrouping, restraint, loading and unloading, transportation duration and climatic factors [65-68]. However, the extent of animal welfare alteration and what can be measured as positive or negative behaviour, if there is any, during this stage has not been clearly defined.

Tarrant et al [26] reported that inability to move and face the preferred direction during transportation caused cattle to lose balance and even fall. However, maintaining balance in a moving vehicle, which is a new experience, while standing and sometimes with little space to move may be hard to achieve. It was also reported that long transportation hours in poor condition transportation vehicles may be unfavourable to animal welfare [26]; while it has also been pointed out that prolonged experience of the same stressor results in familiarity [69-72]. However, Mota-Rojas et al [14] reported that transportation to the abattoir should not take more than 16 hours.

Pre-slaughter stress during transportation has also been reported to influence the immune responses of cattle [73], which may result in the release of stress hormones [74]. Moreover, transportation at high stocking density (above $550 \mathrm{~kg} / \mathrm{m}^{2}$ ) was reported to elevate plasma cortisol $[26,75,76]$. However; validation of these points through blood or urine extraction for hormonal analysis is questionable. The stress hormones surge in these samples may be due to handling or the novel environment (vehicle of arrival at abattoir) during the sampling. Nevertheless, ensuring good transportation is not only of animal welfare and meat quality importance, it is also of economic importance [77].

\section{Abattoir conditions and their impacts}

Miranda-de la Lama et al [78] described the abattoir design as generally based on conventional architectural criteria, such as space optimization or how to facilitate human movement, and not on the behavioural characteristics of the animals. As opposed to the green grass at the farm, abattoirs are mainly concrete and "unnatural". The animal perception and response to the adverse conditions at the abattoir depend on its background and previous experience $[13,43]$. However, animal response behaviour can also be influenced by unfamiliar environments such as concreted abattoir, many abattoir workers [79] and other animals from different farms and of other species [7,63]. For instance, cattle may struggle to adapt with the loud squealing sounds made by pigs during lairaging. Moreover, McGreevy [41] stated that the loud noise at the abattoir affects the animals' response, as opposed to the quiet environment at the farm.

Grandin [80] also reported that cattle perceive the abattoir environment in the same way as at the farm during procedures like vaccination and other managerial processes that involve moving animals through the race. However, there is need to 
clearly classify to what extant can this be expressed. Vimiso et al [10] reported that animal handling differs between the farm and the abattoir. In addition to that, animals would have been exposed to extensive stressors pre-slaughter compared to just farm managerial procedures. The presence of physical distractions (e.g. shiny objects, dangling chains), humans, and change of either dark or light in the race frightens the animal, resulting in anxiety $[22,80]$. However, it was indicated that the animals are not aware that they will die at the abattoir [80]. Grandin $[28,29]$ also reported that use of electric prods, slipping in the stunning box, and missed stuns, sharp edges on equipment or excessive pressure from a restraint device encourages vocalization in beef cattle at the abattoir.

\section{The impact on the quality of meat}

Pre-slaughter handling stress does not only affect the welfare of the animals, but also to a greater extent has an impact on the quality of meat produced from animals of different species $[7,15,16,20,81,82]$. Lawrie [83] recounted that the quality of meat is highly affected by behavioural and physiological response of the animal before slaughter. Pre-slaughter handling affects meat quality attributes, such as colour, $\mathrm{pH}$ and texture $[15,16$, $81,84]$. Stress-related behavioural and physiological changes have been reported to reduce the quality of meat $[85,86]$ through glycogen depletion and elevated ultimate $\mathrm{pH}[16,21,87]$.

Rapid depletion of muscle glycogen during handling, transportation, pre-and post-slaughter results to low lactic acid production; thus dark, firm, and dry meat produced [88]. Glucose in the blood and glycogen in the muscle promotes glycolysis, and thus the formation of lactic acid [89] resulting in tougher meat with higher cooking losses [90,91]. Furthermore, Gajana et al [92] reported that longer transportation time and higher stocking density significantly affected $\mathrm{pH}_{\mathrm{u}}$ and thus reduced meat quality. Warner et al [93] related dark cutting in beef with the time spent in lairage pre-slaughter. While the animal's genetic background and its exposure prior to slaughter determines its behavioural and physiological responses when encountered with stressful situations, this also has an implication on muscle metabolism [13].

Temperamental cattle such as cross-bred steers can be difficult to handle and have an increased responsiveness to stressors; consequently exhibit avoidance behaviour and elevated catecholamine, cortisol and Creatine Kinase $[43,44,51,94,95]$. Furthermore, such animals are more prone to injuries, also referred to as bruising. Strappini et al [96] described bruises as subcutaneous lesions found on a carcass after skinning, during the dressing process. Bruised cattle produce unacceptably higher muscle $\mathrm{pH}(>6.0)$, faster glycogen depletion, muscle darkening, toughening and poor meat shelf-life $[16,95,97]$. Bruising is of economic importance and may result to profit losses due to the bruised parts of the carcass being condemned for human consumption, as well the bruised carcasses being downgraded.
Consumer concerns, laws and regulations governing meat production in the developing world

The developing world such as Africa shows a lot of potential in meat production and export exchange, particularly for beef, due to its ability and resources to accommodate and nurture both indigenous and exotic cattle breeds. Scholtz et al [98] reported that the climatic and agricultural conditions in this part of the world allow for many areas of compatible interest and opportunities, regarding beef cattle production. Bello et al [99] reported that there has been an information gap between the developing and the developed world. Even so, it is also important to realise the geographical, climatic and systematic differences of the two worlds. Therefore, there is need to intensify research in this regard and come up with findings that are suitable and complement the developing world conditions.

Despite the laws and regulations that govern food animals [100], meat production [101] and consumption, Ndou et al [6] described the developing world as giving low priority to the welfare of animals due to factors such as traditional customs and beliefs, lack of knowledge in animal handling and sub-standard handling facilities. This may then make it hard for these countries to compete with the rest of the world due to high prevalence of food insecurity and poverty [6], thus intensifying socioeconomic challenges and constraints [98]. Furthermore; the elevated concerns from consumers on how the animal was treated before it was slaughtered as well as how it was processed (hygiene) affect the way they perceive meat [9].

Bello et al [99] discovered that some abattoirs in Nigeria neglect the practice of regular ante-mortem and post-mortem inspection of slaughter animals, conventional sanitation practices in operation and post-operation cycle thus putting public health in jeopardy due to unsafe meat production. They also reported that these shortcomings threatened achievement of sustainable food safety. Furthermore, Font-I-Furnols et al [102] reported that meat consumers were more concerned of the product's place of origin than its price or the feed the animal took; and they were more comfortable with locally produced meat. However, a study in South Africa revealed that rural consumers were more concerned about the price of the product than any other factor [10]. The current status of the developing world regarding animal welfare awareness and meat quality concerns puts it on the edge relating to import and export participation with the rest of the world through the meat industry in improving the economy. Ferguson et al [103] concluded in a review that the industry should pay attention and even respond to the consumer and societal demands for more sustainable and ethical animal farming systems and practices.

\section{Some possible measures to adjust in order to improve animal welfare and meat quality production}

Through some trials done to investigate the pre and post slaughter exhibition, conclusions and recommendations have 
Table 2. Some proposed methods to improve the welfare of slaughter animals

\begin{tabular}{|c|c|c|}
\hline Recommendation & Description & Reference \\
\hline \multicolumn{3}{|l|}{ Supplementation with: } \\
\hline 1. Magnesium & 1. Stress reduction and improves meat quality & Ferguson and Warner [7] \\
\hline 2. Tryptophan & 2. Minimize stress & \\
\hline 3. Electrolytes & 3. Increases carcass yields & \\
\hline Nutrition modulation and electrolyte therapy & $\begin{array}{l}\text { Reduction of stress during transportation and handling thus improving } \\
\text { meat quality }\end{array}$ & Schaefer et al [65] \\
\hline Use of proper facilities and handling techniques & Allows good management and improved welfare and production & $\begin{array}{l}\text { Grandin [3], Ferguson and Warner [7], } \\
\text { Petherick [112] }\end{array}$ \\
\hline Stockmanship improvement & $\begin{array}{l}\text { A good relationship between farm animals and humans reduces animals } \\
\text { fear and allows ease during handling }\end{array}$ & $\begin{array}{l}\text { Grandin [3], Ndou et al [6], Hemsworth } \\
\text { et al [20], Waiblinger et al [109], }\end{array}$ \\
\hline Practise early life animal-human interactions & Encourages good relationship even at the later stage thus good production & Probst et al $[58,4]$ \\
\hline Selection for temperament & Use of less aggressive breeds thus improved handling and meat quality & Ferguson and Warner [7] \\
\hline
\end{tabular}

been reported in trying to minimise pre-slaughter stress and thus improve meat quality $[8,11,15,16,29]$. In addition, Chulayo and Muchenje [104] reported that to ensure good production, animal welfare should be prioritized in all production sectors; on the farm, during transportation and at the abattoir. Some recommendations that have been drafted are described in Table 2 .

\section{Knowledge empowerment and enforcement}

Through further research on the gaps identified in this paper, more knowledge generated can be of great addition. Furthermore, ease of information transformation from researchers to farmers in an understandable and simple manner still requires establishing. Methods like regular workshops, magazine articles, blogging and social networks may assist. Sequentially, this knowledge may be easily imparted to the stockman and everyone else involved in animal handling in both farms and abattoirs. To ensure maximum product quality and economic returns, everyone in the production chain (the stockman, farmer, transporter, abattoir worker, the designers of animal facilities and consumers) must be well-informed of animal welfare and its subsequent effects on meat product quality [18].

\section{Merging farms with abattoirs}

In addition, to eliminate the pre-slaughter transportation stress, bringing the fattening/feedlot facilities closer to the slaughter house (Figure 2) may improve the situation. Animals can be transported to these facilities at least 2 to 3 months prior the slaughter date such that herding them by foot to the abattoir would be possible. The abattoirs may adopt this either individually or co-joined with their regular suppliers. This could be viewed as an investment because installation would be a once off cost with long term benefits. Though literature has reported that cattle prefer extensive conditions over confinement $[53,105,106]$, this has a potential to improve animal adaptation to the abattoir workers, surrounding conditions, as well as increasing profit in the long run. A similar scenario can be observed in pasture-based dairy farms, where animals are hoofed for 1 to $3 \mathrm{~km}$ to the milking parlour once or twice a day for milking. Some abattoirs in South Africa already have farms where they fatten their constant supply of beef cattle. However, just like privately owned farms, they are situated remotely from the abattoir and thus require the use of transportation vehicles to move animals before slaughter. Though feedloting was reported

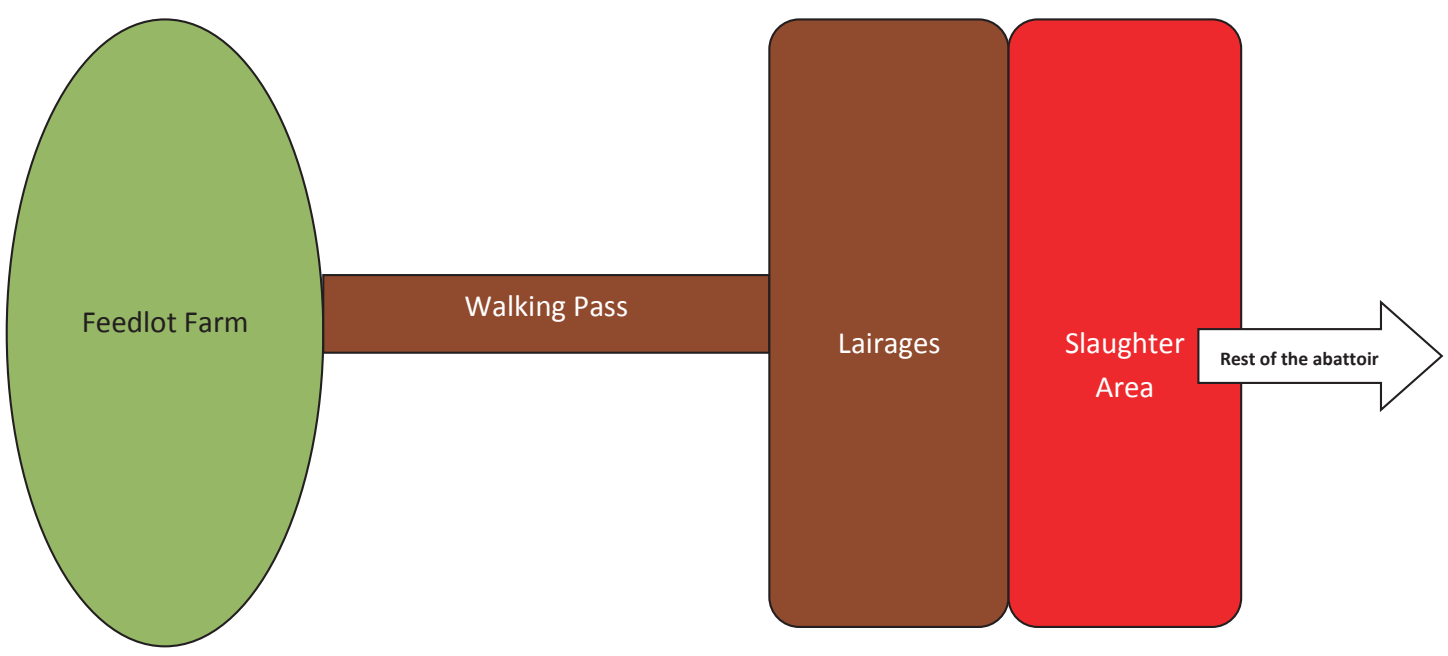

Figure 2. A proposed model for bringing the feedlot farms closer to the abattoirs in trying to minimize transportation stress. 
to be unfriendly towards animal welfare due to confinement [53], Vimiso and Muchenje [97] reported that animals that were hoofed to the abattoir had lower bruising scores compared to those that were transported either directly from the farm or through auctions.

\section{Technology advancement in abattoirs}

Livestock of all species often react and refuse to move in the handling facilities due to stress and anxiety if they spot a distraction or are separated from their groups $[22,43,80]$. However, as opposed to using electric probes to motivate animal movement, upgrading and use of automated machinery to convey animals might be helpful. Some commercial abattoirs use conveyer restrainers for pigs and sheep $[35,36]$, which reduce strain on both animals and handlers during heading. Furthermore, Gregory [31] reported that for effective and animal welfare friendly results, it is important to understand the causes of variation in captive bolt gun performance, the efficiency of poll vs frontal shooting and the prevalence of false aneurysms in carotid arteries during shechita and halal slaughter methods. These slaughter methods are religion based and it is mandatory that they be performed by specialised personnel of that religion. Shechita (Jewish) slaughter involves swiftly severing the trachea, carotid arteries and jugular veins using a specialised knife called hallaf, without stunning the animal; while halal slaughter may involve a "religiously acceptable stunning" followed by severing the carotid arteries and jugular veins in a single wipe [107].

\section{CONCLUSION}

Animal welfare and the quality of meat produced by farmed animals are dependent on all the chain activities to which they are subjected to from birth till slaughter. However, there is lack of clear definition in some areas. There is still need to further investigate this area, interlinking the independent discoveries and information that has been found through studies on some of the contributing factors. Furthermore, the developing world needs to fully investigate, adopt and commit to some of the world's standard on animal management and meat production thus improving its food security and economy through the use of its maximum potential. It is also important to note that what works for the developed world might not be working in the developing world, hence the need to intensively investigate the matter.

\section{CONFLICT OF INTEREST}

We certify that there is no conflict of interest with any financial organization regarding the material discussed in the manuscript.

\section{ACKNOWLEDGMENTS}

The authors would like to thank the National Research Foundation (NRF): Innovation Doctoral Scholarship (Grant UID: 86113) and Red Meat Research and Development of South Africa (RMRDSA- Authorization number: IT8114/98) for funding this research.

\section{REFERENCES}

1.Boissy A, Erhard HW. Chapter 3: How studying interactions between animal emotions, cognition, and personality can contribute to improve farm animal welfare. 2nd ed. In: Grandin T, Deesing MJ, editors. Genetics and the behaviour of domestic animals. San Diego, CA: Academic Press; 2014. p. 81-113.

2.Waiblinger SC, Boivin X, Pedersen V, et al. Assessing the humananimal relationship in farmed species: A critical review. Appl Anim Behav Sci 2006;101:185-242.

3.Grandin T. Transferring results of behavioural research to industry to improve animal welfare on the farm, ranch and slaughter plant. Appl Anim Behav Sci 2003;81:215-28.

4.Probst JK, Hillmann E, Leiber F, Kreuzer M, Neff AS. Influence of gentle touching applied few weeks before slaughter on avoidance distance and slaughter stress in finishing cattle. Appl Anim Behav Sci 2013;144:14-21.

5.Probst JK, Neff AS, Hillmann E, et al. Relationship between stressrelated exsanguination blood variables, vocalisation, and stressors imposed on cattle between lairage and stunning box under conventional abattoir conditions. Livest Sci 2014;164:154-8.

6.Ndou SP, Muchenje V, Chimonyo M. Assessment and implications of animal welafere in beef production systems in developing countries. Afr J Biotechnol 2011;10:1049-64.

7.Ferguson DM, Warner RD. Have we underestimated the impact of pre-slaughter stress on meat in ruminants? Meat Sci 2008;80: 12-19.

8.Miranda-de la Lama GC, Villarroel M, María GA. Livestock transport from the perspective of the pre-slaughter logistic chain: A review. Meat Sci 2014;98:9-20.

9.Grandin T. Animal welfare and society concerns finding the missing link. Meat Sci 2014;98:461-9.

10. Vimiso P, Muchenje V, Marume U, Chiruka R. Preliminary study on consumers' and meat traders' perceptions of beef quality and how the beef quality is affected by animal welfare practices. Sci Res Essays 2012;7:2037-48.

11. Grandin T. Assessment of stress during handling and transport. J Anim Sci 1997;75:249-57.

12. de Passille AM, Rushen J. Can we measure human-animal interactions in on-farm animal welfare assessment? Some unresolved issues. Appl Anim Behav Sci 2005;92:193-209.

13. Terlouw C. Stress reactions at slaughter and meat quality in pigs: genetic background and prior experience: A brief review of recent findings. Livest Prod Sci 2005;94:125-35.

14. Mota-Rojas D, Becerril M, Lemus C, et al. Effects of mid-summer transport duration on pre- and post-slaughter performance and 
pork quality in Mexico. Meat Sci 2006;73:404-12.

15. Muchenje V, Dzama K, Chimonyo M, et al. Some biochemical aspects pertaining to beef eating quality and consumer health: A review. Food Chem 2009;112:279-89.

16. Muchenje V, Dzama K, Chimonyo M, Strydom PE, Raats JG. Relationship between pre-slaughter stress responsive and beef quality in three cattle breeds. Meat Sci 2009;81:653-7.

17. Chulayo AY, Tada O, Muchenje V. Research on pre-slaughter stress and meat quality: A review of challenges faced under practical conditions. Appl Anim Husb Rural Dev 2012;5:1-6.

18. Broom DM, Fraser AF. Domestic animal behaviour and welfare. 4th ed. Wallingford, UK: CAB International; 2007.

19. Broom DM. Welfare assessment and problem areas during handling and transport. In: Grandin, T editor, Livestock Handling, Transport. 2nd ed. Wallingford, UK: CABI; 2000. p. 43-61.

20. Hemsworth PH, Rice M, Karlen MG, et al. Human-animal interactions at abattoirs: Relationships between handling and animal stress in sheep and cattle. Appl Anim Behav Sci 2011;135:24-33.

21. O'Neill HA, Webb EC, Frylinck L, Strydom PE. The stress responsiveness of three different breed types and the effect on ultimate $\mathrm{pH}$ and meat colour. In: Proceedings of 52nd International congress of meat science and technology from 13 to 18 August 2006; Dublin, Ireland. 2006. p. 181-2.

22. Bourguet C, Deiss V, Tannugi CC, Terlouw EMC. Behavioural and physiological reactions of cattle in a commercial abattoir: Relationships with organisational aspects of the abattoir and animal characteristics. Meat Sci 2011;88:158-68.

23. Boissy A. Fear and fearfulness in determining behaviour. In: Grandin T, editor. Genetics and behaviour of domestic animals. San Diego, CA: Academic Press; 1998. p. 67-111.

24. Raussi S. Human-Cattle interactions in group housing. Appl Anim Behav Sci 2003;80:245-62.

25. Tarrant PV. Transportation of cattle by road. Appl Anim Behav Sci 1990;28:153-70.

26. Tarrant PV, Kenny FJ, Harrington D, Murphy M. Long distance transportation of steers to slaughter: effect of stocking density on physiology, behaviour, and carcass quality. Livest Prod Sci 1992; 30:223-38.

27. Minka NS, Ayo JO. Physiological and behavioural responses of goats to 12-hour road transportation, lairage and grazing periods, and the modulatory role of ascorbic acid. J Vet Behav 2013;8:349-56.

28. Grandin T. The feasibility of using vocalization scoring as an indicator of poor welfare during cattle slaughter. Appl Anim Behav Sci 1998;56:121-8.

29. Grandin T. Cattle vocalizations are associated with handling and equipment problems in beef slaughter plants. Appl Anim Behav Sci 2001;2:191-201.

30. Gregory NG. Recent concerns about stunning and slaughter. Meat Sci 2005;70:481-91.

31. Gregory NG. Animal welfare at markets and during transport and slaughter. Meat Sci 2008;80:2-11.

32. Gregory NG, Fielding HR, von Wenzlawowicz M, von Holleben K.
Time to collapse following slaughter without stunning in cattle. Meat Sci 2010;85:66-9.

33. Gregory NG, Schuster P, Mirabito L, Kolesar R, McManus T. Arrested blood flow during false aneurysm formation in the carotid arteries of cattle slaughtered with and without stunning. Meat Sci 2012;90: 368-72.

34. Agbeniga B, Webb EC. Effect of slaughter technique on bleed-out, blood in the trachea and blood splash in the lungs of cattle. S Afr J Anim Sci 2012;42: 524-29.

35. Njisane YZ, Muchenje V. Influence of municipal abattoir conditions and animal-related factors on avoidance-related behaviour, bleeding times at slaughter and the quality of lamb meat. Asian-Australas J Anim Sci 2013;26:1496-503.

36. Njisane YZ, Muchenje V. Quantifying avoidance-related behaviour and bleeding times of sheep of different ages, sex and breeds slaughtered at a municipal and a commercial abattoir. S Afr J Anim Sci 2013;43:S38-S42.

37. Farouk MM. Advances in the industrial production of Halal and Kosher red meat. Meat Sci 2013;95:805-20.

38. Farouk MM, Al-Mazeedi HM, Sabow AB, et al. Halal and Kosher slaughter methods and meat quality: A review. Meat Sci 2014;98: 505-19.

39. Farouk MM, Regenstein JM, Pirie MR, et al. Spiritual aspects of meat and nutritional security: Perspectives and responsibilities of the Abrahamic faiths. Food Res Int 2015;76:882-95.

40. Grandin T. Observations of cattle behaviour applied to the design of cattle handling facilities. Appl Anim Behav Sci 1980;6:19-31.

41. McGreevy P. Notes on some topics in applied animal behaviour [Internet]. In: Chapter 5, Design of facilities for management of livestock; 2003 [Cited 2012 Jan 17]. Available from: www.animal behaviour.net

42. Dodzi MS, Muchenje V. Avoidance-related behavioural variables and their relationship to milk yield in pasture-based dairy cows. Appl Anim Behav Sci 2011;133:11-7.

43. Grandin T. Behavioural agitation during handling of cattle is persistent over time. Appl Anim Behav Sci 1993;36:1-9.

44. Voisinet BD, Grandin T, O'Connor SF, Tatum JD, Deesing MJ. Bos indicus-cross feedlot cattle with excitable temperaments have tougher meat and a higher incidence of borderline dark cutters. Meat Sci 1997;46:367-77.

45. Hansen I, Cristiansen F, Hansen HS, Braastad B, Bakken M. Variation in behaviour response of ewes towards predator-related stimuli. Appl Anim Behav Sci 2001;70:227-37.

46. Lambe NR, Conington J, Bishop SC, Waterhouse A, Simm G. A genetic analysis of maternal behaviour score in Scottish Blackface sheep. J Anim Sci 2001;72:415-25.

47. Vierin M, Bouisson MF. Responses of weaned lambs to fear eliciting situations: origin of individual differences. Dev Psychobiol 2003; 42:131-47.

48. Dodd CL, Pitchford WS, Edwards JEH, Hazel SJ. Measures of behavioural reactivity and their relationships with production traits in sheep: A review. Appl Anim Behav Sci 2012;140:1-15. 
49. Strappini AC, Frankena K, Metz JHM, Gallo CB, Kemp B. Prevalence and risk factors for bruises in Chileon bovine carcasses. Meat Sci 2010;86:859-64.

50. Dweyer C. The behaviour of sheep and goats. In: Jensen P, editor. The Ethology of domestic animals, An introductory text. 2nd ed. Wallingford, UK: CABI; 2009. p. 161-76.

51. Njisane YZ. Farm to abattoir conditions and their subsequent effects on behavioural and physiological changes and the quality of beef from extensively-reared Nguni and non-descript steers [ $\mathrm{PhD}$ thesis]. Alice, South Africa: University of Fort Hare; 2016.

52. Weeks CA, McNally PW, Warriss PD. Influence of the design of facilities at auction markets and animal handling procedures on bruising in cattle. Vet Rec 2002;150:743-8.

53. Lee C, Fisher AD, Colditz IG, Lea JM, Ferguson DM. Preference of beef cattle for feedlot or pasture environments. Appl Anim Behav Sci 2013;145:53-9.

54. Breed MD, Moore J. Chapter 4 - Homeostasis and Time Budgets (Abstract). In: Breed DB, Moore J, editors, Animal behaviour. 2nd ed. San Diego, CA: Academic Press; 2016. p. 104-44.

55. Breuer K, Hemsworth PH, Barnett JL, Matthews RL, Coleman GJ. Behavioural response to humans and the productivity of commercial dairy cows. Appl Anim Behav Sci 2000;66:273-88.

56. Mounier L. On-farm welfare assessment in dairy cattle, improving animal welfare: a practical approach. Presented in Barcelona, 1-2 December 2011. Directorate-General for health and consumers. 2011.

57. Markowitz TM, Dally MR, Gursky K, Price EO. Early handling increases lamb affinity for humans. Appl Anim Behav Sci 1998; 55:573-87.

58. Probst JK, Neff AS, Leiber F, Kreuzer M, Hillmann E. Gentle touching in early life reduces avoidance distance and slaughter stress in beef cattle. Appl Anim Behav Sci 2012;139:42-9.

59. Lay Jr. DC, Friend TH, Grissom KK, Hale RL, Bowers CL. Novel breeding box has variable effects on heart rate and cortisol response of cattle. Appl Anim Behav Sci 1992;35:1-10.

60. Boissy A, Veissier I, Roussel S. Behavioural reactivity affected by chronic stress: an experimental approach in calves submitted to environmental instability. Anim Welf 2001;10:175-85.

61 . Hutson GD. The influence of barley food rewards on sheep involvement through a handling system (Cited by Grandin, 1993). Appl Anim Behav Sci 1985;14:263-73.

62. Pascoe PJ. Humaneness of electrical immobilization unit for cattle (Cited by Grandin, 1993). Am J Vet Res 1986;10:2252-6.

63. Hemsworth PH, Coleman GJ. Human-Livestock interactions. In: The stockperson and the productivity of intensively farmed animals. Wallingford, CT: CAB International; 1998.

64. Warriss PD. Meat Science: An introductory text. Wallingford, UK: CAB International; 2000. p. 312.

65. Schaefer AL, Jones SDM, Stanley RW. The use of electrolyte solutions for reducing transport stress. J Anim Sci 1997;75:258-65.

66. Mitchell MA, Kettlewell PJ. Physiological and welfare of broiler chickens in transit; solutions not problems! Poult Sci 1998;77:
1803-14.

67. Swanson JC, Morrow-Tesch J. Cattle transport: Historical, research, and future perspectives. J Anim Sci 2001;79:E102-E9.

68. Kadim, IT, Mahgoub O, Al-Kindi A, Al-Marzooqi W, Al-Saqri NM. Effects of transportation at high ambient temperatures on physiological responses, carcass and meat quality characteristics of three breeds of Omani goats. Meat Sci 2006;73:626-34.

69. Knowles TG. A review of the road transportation of cattle. Vet Rec 1999;144:197-201.

70. Honkavaara M., Rintasalo E, Ylonenand J, Pudas T. Meat quality and transport stress in cattle. Dtsch Tierarztl Wochenschr 2003; 110:125-8.

71. Knights M, Smith GW. Decreased ACTH secretion during prolonged transportation stress is associated with reduced pituitary responsiveness to tropic hormone stimulation in cattle. Domest Anim Endocrinol 2007;33:442-50.

72. Leme TMC, Titto EAL, Titto CG, Periera AMF. Influence of transportation methods and pre-slaughter rest periods on cortisol levels in lambs. Small Rumin Res 2012;107:8-11.

73. Hulbert LE, Carroll JA, Burdick NC, et al. Innate immune responses of temperamental and calm cattle after transportation. Vet Immunol Immunopathol 2011;143:66-74.

74. Odore R, D’Angelo A, Badino P, et al. Road transportation affects blood hormone levels and lymphocyte glucocorticoid and b-adrenergic receptor concentrations in calves. Vet J 2004;168:297-03.

75. Tarrant PV, Kenny FJ, Harrington D. The effect of stocking density during 4 hour transport to slaughter on behaviour, blood constituents and carcass bruising in Friesian steers. Meat Sci 1988;24: 209-22.

76. Kadim IT, Mahgoub O, Al-Marzooqi W, et al. Effects of transportation during the hot season and low voltage electrical stimulation on histochemical and meat quality characteristics of sheep longissimus muscle. Livest Sci 2009;126:154-61.

77. Whiting TL. Comparison of minimum space allowance standards for transportation of cattle by road from 8 authorities. Can Vet J 2000;41:855-60.

78. Miranda-de la Lama GC, Villarroel M, Liste G, Escosa J, María GA. Critical points in the pre-slaughter logistic chain of lambs in Spain that may compromise the animal's welfare. Small Rumin Res 2010;90:174-8.

79. Terlouw EMC, Porcher J. Repeated handling of pigs during rearing. I. Refusal of contact by handler and reactivity to familiar and unfamiliar humans. J Anim Sci 2005;83:1653-63.

80. Grandin T. Progress and challenges in animal handling and slaughter in the US: Sentience in animals. Appl Anim Behav Sci 2006;100: 129-39.

81. Muchenje V, Dzama K, Chimonyo M, Raats JG, Strydom PE. Meat quality of Nguni, Bonsmara and Aberdeen Angus steers raised on natural pasture in the Eastern Cape, South Africa. Meat Sci 2008;79:20-8.

82. Cetin O, Bingol EB, Colak H, Hampikyan H. Effects of electrical stimulation on meat quality of lamb and goat meat. Sci World J 
2012;574202.

83. Lawrie RD. Metabolic stress which affect muscle. In: Briskey EJ, Cassens RG, Trautman JC editor, The physiology and biochemistry of muscle as a food. Madison, WI: University of Wisconsin Press; 1966. p. 137-64.

84. Lahucky R, Palanska O, Mojto J, Zaujec K, Huba J. Effect of preslaughter handling on muscle glycogen level and selected meat quality traits in beef. Meat Sci 1998;50:389-93.

85. Warriss PD. Animal Welfare - handling animals before slaughter and the consequences for welfare and product quality. Oxon, England: Meat Focus International (July issue); 1992. p.135-138.

86. Young JF, Bertram HC, Oksbjerg N. Rest before slaughter ameliorates pre-slaughter stress-induced increased drip loss but not stressinduced increase in the toughness of pork. Meat Sci 2009;83:63441.

87. Wood JD, Holder JS, Main DCJ. Quality assurance schemes. Proceedings of the International Congress of Meat Science and Technology; Barcelona, Spain: 1998;44:206-215.

88. FAO Corporate Document Repository. Guidelines for slaughtering meat cutting and further processing. FAO Animal production and health paper. 199191:170.

89. Choe JH, Choi YM, Lee SH, et al. The relation of blood glucose level to muscle fiber characteristics and pork quality traits. Meat Sci 2009;83:62-7.

90. Warner RD, Ferguson DM, Cottrell JJ, Knee BW. Acute stress induced by the pre-slaughter use of electrical prodders causes tougher beef meat. Aust J Exp Agric 2007;47:782-8.

91. Gruber SL, Tatum JD, Engle TE, et al. Relationships of behavioural and physiological symptoms of pre-slaughter stress to beef longissimus muscle tenderness. J Anim Sci 2010;88:1148-59.

92. Gajana CS, Nkukwana TT, Marume U, Muchenje V. Effects of transportation time, distance, stocking density, temperature and lairage time on incidences of pale soft exudative (PSE) and the physico-chemical characteristics of pork. Meat Sci 2013;95:520-5.

93. Warner RD, Truscot TG, Eldridge GA, Franz PR. A survey of the incidence of high $\mathrm{pH}$ beef meat in Victorian abattoirs. In 34th International Congress of Meat Science and Technology. Brisbane, Australia; 1998. p.150-151.

94. Curley J, Neuendorff DA, Lewis AW, et al. Functional characteristics of the bovine hypothalamicpituitary- adrenal axis vary with temperament. Horm Behav 2008;53:20-7.

95. Mpakama T, Chulayo AY, Muchenje V. Bruising in slaughter cattle and its relationship with creatine kinase levels and beef quality as affected by animal related factors. Asian-Australas J Anim Sci 2014; 27:717-25

96. Strappini AC, Frankena K, Metz JHM, Gallo CB, Kemp B. Characteristics of bruises in carcasses of cows sourced from farms or from livestock markets. Anim 2012;6:502-9.

97. Vimiso P, Muchenje V. A survey on the effect of transport method on bruises, $\mathrm{pH}$ and colour of meat from cattle slaughtered at a South African commercial abattoir. S Afr J Anim Sci 2013;43:
105-11.

98. Scholtz MM, McManus C, Okeyo AM, Theunissen A. Opportunities for beef production in developing countries of the southern hemisphere. Livest Sci 2011;142:195-202.

99. Bello M, Lawan MK, Aluwong T, Sanusi M. Management of slaughter houses in northern Nigeria and the safety of meat produced for human consumption. Food Control 2015; 49:34-9.

100.Animal Protection Act 1962. Act No. 71 of 1962. [Cited 2013 Aug]. Available from: http://www.daff.gov.za/doaDev/sideMenu/acts/ 11\%20Animal\%20Protection\%20No71\%20(1962).pdf

101.Meat Safety Act 2000. Act No. 40 of 2000. [Cited 2013 Aug] http:// www.daff.gov.za/doaDev/sideMenu/acts/21\%20Meat\%20Safety\%20 No40\%20(2000).pdf

102.Font-I-Furnols M, Realini C, Montossi F, et al. Consumer's purchasing intention for lamb meat affected by country of origin, feeding system and meat price: A conjoint study in Spain, France and United Kingdom. Food Qual Pref 2011;22:443-51.

103.Ferguson DM, Schreurs NM, Kenyon PR, Jacob RH. Balancing consumer and societal requirements for sheep meat production: An Australasian perspective. Meat Sci 2014;98:477-83.

104. Chulayo AY, Muchenje V. A balanced perspective on animal welfare for improved meat and meat products. S Afr J Anim Sci 2015;45: 452-69.

105.Krohn CC, Munksgaard L, Jonasen B. Behavior of dairy cows kept in extensive (loose housing pasture) or intensive (tie stall) environments. 1. Experimental procedure, facilities, time budgets - diurnal and seasonal conditions. Appl Anim Behav Sci 1992;34:37-47.

106.Legrand AL, Keyserlingk MAG, Weary DM. Preference and usage of pasture versus free-stall housing by lactating dairy cattle. J Dairy Sci 2009;92:3651-8.

107.Meikle J. What exactly does the halal method of animal slaughter involve? 2014. [Cited 2016 Aug 11]. Available from: https://www. theguardian.com/lifeandstyle/2014/may/08/what-does-halal-methodanimal-slaughter-involve

108. Wemelsfelder F, Hunter TEA, Mendl MT, Lawrence AB. Assessing the 'whole animal': a free choice profiling approach. Anim Behav 2001;62:209-20.

109. Waiblinger S, Menke C, Fölsch DW. Influences on the avoidance and approach behaviour of dairy cows towards humans on 35 farms. Appl Anim Behav Sci 2003;84:23-39.

110.Minero M, Tosi MV, Canali E, Wemelsfelder F. Quantitative and qualitative assessment of the response of foals to the presence of an unfamiliar human. Appl Anim Behav Sci 2009;116:74-81.

111.Stockman CA, McGilchrist P, Collins T, et al. Qualitative behavioural assessment of Angus steers during pre-slaughter handling and relationship with temperament and physiological responses. Appl Anim Behav Sci 2012;142:125-33.

112.Petherick JC. Animal welfare issues associated with extensive livestock production: The northern Australian beef cattle industry. Appl Anim Behav Sci 2005;92:211-34. 